\title{
Can Aurelia (Cnidaria, Scyphozoa) species be differentiated by comparing their scyphistomae and ephyrae?
}

\author{
Maria GAMBILL ${ }^{1} \&$ Gerhard JARMS ${ }^{2}$ \\ ${ }^{1}$ Institute of Hydrobiology and Fisheries Science, University of Hamburg, Olbersweg 24, \\ 22767 Hamburg, Germany. \\ Email: mariagambill@hotmail.com (corresponding author) \\ ${ }^{2}$ Zoological Institute and Museum, University of Hamburg, Martin-Luther-King Platz 3, \\ 20146 Hamburg, Germany. \\ ${ }^{1}$ urn:1sid:zoobank.org:author:43164A98-3AF4-4DB7-8AAF-C2464B1ABC22 \\ ${ }^{2}$ urn:1sid:zoobank.org:author:76C2ADDC-93D8-4A13-BC4F-36F44727CC25
}

\begin{abstract}
Debate exists regarding the number of species of the moon jellyfish (genus Aurelia), a common member of the planktonic community of the coastal shelf seas around the world. Three Aurelia congeners (A. aurita, A. labiata and A. limbata) are currently considered to exist but recent genetic analyses suggested that this is an oversimplification. We analyzed the morphological characteristics of scyphistomae, morphological characteristics of ephyrae and differences in the time span of the strobilation process of Aurelia congeners from 17, 7 and 6 different source populations, respectively, of known species. Morphological characteristics of scyphistomae were similar among the 17 populations but those of ephyrae, such as the shape and form of lappets, were effective discriminators in the 6 cases examined. We recommend identifying species based on differences in 1) the morphological characteristics of scyphistomae and ephyrae (and not only medusae), 2) the genetics of individuals, and 3 ) the geographical occurrence of the population. This study adds to the growing body of knowledge on scyphozoan scyphistomae and ephyrae, stages of the metagenic life cycle of scyphozoans that have received relatively little study compared to medusae.
\end{abstract}

Keywords. Polyps, jellyfish, strobilation, nomenclature, morphology.

Gambill M. \& Jarms G. 2014. Can Aurelia (Cnidaria, Scyphozoa) species be differentiated by comparing their scyphistomae and ephyrae? European Journal of Taxonomy 107: 1-23. http://dx.doi.org/10.5852/ejt.2014.107

\section{Introduction}

The perceived increased frequency of blooms of jellyfish in the world's ocean (Mills 2001; Purcell et al. 2007; Purcell 2012; Condon et al. 2012, 2013; Lee et al. 2013) has intensified research efforts to understand the population dynamics of gelatinous plankton, with the majority of research having been conducted on the conspiculous medusoid life stages (Lucas et al. 2012). Medusae in the genus Aurelia Lamarck, 1816 have been reported to occur in the world's oceans from $70^{\circ} \mathrm{N}$ to $40^{\circ} \mathrm{S}$ where they are most commonly found along continental shelves or close to large islands (Mayer 1910; Kramp 1961; Russell 1970; Miyake et al. 2002; Schroth et al. 2002). Despite >100 years of research on Aurelia, the 
taxonomy of the genus is still unclear. The genus was originally described as 'Aurellia', which was changed to 'Aurelia' by Rees (1957). It had three species: A. aurita (Linné, 1758), the Pacific A. labiata Chamisso \& Eysenhardt, 1820 and A. maldivensis Bigelow, 1904 from the Indian Ocean (Linné 1758; Chamisso \& Eysenhardt 1820; Bigelow 1904). Debate existed on whether A. labiata and/or A. limbata Brandt, 1838 were valid members of the genus (Brandt 1838). Kramp (1961) described six different species of Aurelia, whereas Russell (1970) declared that only A. aurita and A. limbata were valid species. Gershwin (2001) provided a new description of A. labiata and reported it to be endemic to coastal areas of the Eastern Pacific. Although three species (A. aurita, A. labiata and A. limbata) are currently morphologically considered to comprise the genus (Wrobel \& Mills 1998; Gershwin 2001; Miyake et al. 2002; Albert 2005; Widmer 2005), genetic analyses have suggested a more complex situation, including five cryptic species of Aurelia in the North Pacific and up to nine species worldwide (Dawson \& Jacobs 2001; Dawson \& Martin 2001; Schroth et al. 2002; Dawson 2003; Dawson et al. 2005).

The vast majority of studies using morphology to distinguish species of Aurelia has examined medusae, while only five studies (Uchida \& Nagao 1963; Gershwin 2001; Straehler-Pohl 2009; Straehler-Pohl \& Jarms 2010; Straehler-Pohl et al. 2011) have considered the morphology of scyphistomae and ephyrae. It is known that scyphistoma populations of scyphozoan jellyfish can be distinguished not only by using morphological features but also by analyzing asexual propagation as well as the timing and intermittency of strobilation (e.g., Condon 2001; Lucas 2001; Ma \& Purcell 2005; Willcox et al. 2007; Adler \& Jarms 2009; Straehler-Pohl 2009; Holst 2012a). Documenting the morphological characteristics of scyphistomae and ephyrae can not only (potentially) help clarify the taxonomic status of the genus Aurelia, but advancing our knowledge on the strobilation of Aurelia scyphistomae is also an important step towards understanding the bloom dynamics of members of this genus (Lucas 2001; Purcell 2007; Purcell et al. 2012).

We examined aspects of the morphology of scyphistomae and ephyrae and the strobilation dynamics of Aurelia populations collected from 17 locations around the world. Populations were from three species and we tested whether the same species assignments would be made using morphological measurements of scyphistomae and ephyrae. We also measured characteristics of strobilation (duration, number of ephyrae per scyphistoma), contrasting Pacific from Atlantic populations. We performed these comparisons not only to help clarify the taxonomic status of the genus but also to gain knowledge of basic features of scyphistomae and their reproductive dynamics in the laboratory.

\section{Material and methods}

\section{Cultures}

We compared the morphology of scyphistomae and ephyrae from populations of Aurelia collected at 17 locations in the North and Baltic Seas as well as the Atlantic and Pacific Oceans (Table 1). A priori species identifications were: populations 1 to $14=A$. aurita, populations 15 and $16=$ A. labiata, and culture $17=$ A. limbata. Species-level identifications were made a priori based on the morphology of medusae. Scyphistomae were kept in culture for more than 5 years. Scyphistomae and ephyrae were cultured using natural seawater at temperatures (SANYO incubators MIR 553 and MIR 253) and salinities (ATAGO S7Mill refractometer) that represented their local conditions (Table 1).

Scyphistomae were kept in 150-ml glass bowls in darkness and ephyrae were maintained in aerated, $500-\mathrm{ml}$ flasks in daylight with the photoperiods occurring between May $5^{\text {th }}$ and September $23^{\text {rd }} 2009$ in Hamburg, Germany, and room temperature $\left(18\right.$ to $\left.21^{\circ} \mathrm{C}\right)$. Based on previous work, we tried to induce strobilation by first decreasing the temperature and then raising it again to the initial temperature (Holst 2008, Holst 2012a). In 14 cultures (all except cultures 6 and 14 because strobilation was happening already on a regular basis) temperature was set from $15^{\circ} \mathrm{C}$ to $10^{\circ} \mathrm{C}$ and back to $15^{\circ} \mathrm{C}$ after 7 days. In 
Table 1. Origin, salinity and incubation temperature of 17 different cultures of Aurelia sp. Strobilation was induced by temperature drop and, if required, additional potassium iodine (KI).

\begin{tabular}{|c|c|c|c|c|c|c|c|c|}
\hline \multirow{2}{*}{ Culture } & \multirow{2}{*}{$\begin{array}{l}\text { Proposed } \\
\text { species } \\
\text { (a priori) }\end{array}$} & \multirow{2}{*}{ Origin } & \multirow{2}{*}{ Location } & \multirow{2}{*}{ long /lat } & \multirow{2}{*}{$\begin{array}{l}\text { Salinity } \\
\text { (psu) }\end{array}$} & \multicolumn{3}{|c|}{ Temperature $\left({ }^{\circ} \mathrm{C}\right)$} \\
\hline & & & & & & Scyphistomae & Strobilation & Ephyrae \\
\hline 1 & \multirow{14}{*}{ A. aurita } & North Sea & $\begin{array}{c}\text { Sylt, } \\
\text { Germany }\end{array}$ & N 5502’32” E 8²4’40” & 34 & $10-15$ & 10 & $\begin{array}{l}\text { Room temp } \\
\left(18-22^{\circ} \mathrm{C}\right)\end{array}$ \\
\hline 2 & & North Sea & $\begin{array}{l}\text { Helgoland, } \\
\text { Germany }\end{array}$ & N 5410’50” E 752’50” & 34 & $10-15$ & $10(\mathrm{KI})$ & $\begin{array}{l}\text { Room temp } \\
\left(18-22^{\circ} \mathrm{C}\right)\end{array}$ \\
\hline 3 & & $\begin{array}{l}\text { Northeast } \\
\text { Atlantic }\end{array}$ & $\begin{array}{l}\text { Hebrides, } \\
\text { Scotland }\end{array}$ & $\mathrm{N} 57^{\circ} 36^{\prime} 01^{\prime \prime} \mathrm{W} 7^{\circ} 0{ }^{\prime} 01^{\prime \prime}$ & 34 & $10-15$ & & \\
\hline 4 & & Baltic Sea & $\begin{array}{c}\text { Boiensdorf, } \\
\text { Germany }\end{array}$ & N 5401'57”' E 11³3’16” & 20 & $10-15$ & & \\
\hline 5 & & Baltic Sea & $\begin{array}{l}\text { Strande, } \\
\text { Germany }\end{array}$ & $\mathrm{N} 54^{\circ} 26^{\prime} 10^{\prime \prime} \mathrm{E} 10^{\circ} 10^{\prime} 21^{\prime \prime}$ & 20 & $10-15$ & & \\
\hline 6 & & East Atlantic & $\begin{array}{l}\text { Roscoff, } \\
\text { France }\end{array}$ & N48 $43^{\prime} 40^{\prime \prime} \mathrm{W} 3^{\circ} 59^{\prime} 07^{\prime \prime}$ & 34 & 15 & 15 & $\begin{array}{c}\text { Room temp } \\
\left(18-22^{\circ} \mathrm{C}\right)\end{array}$ \\
\hline 7 & & Arctic Ocean & White Sea & N65³3’49”E36³6’33” & 34 & $10-15$ & & \\
\hline 8 & & $\begin{array}{l}\text { North Sea/ } \\
\text { Skagerrak }\end{array}$ & $\begin{array}{l}\text { Kristineberg, } \\
\text { Sweden }\end{array}$ & N58 $14^{\prime} 59^{\prime \prime}$ E11 ${ }^{\circ} 26^{\prime} 57^{\prime \prime}$ & 34 & $10-15$ & $10(\mathrm{KI})$ & $\begin{array}{l}\text { Room temp } \\
\left(18-22^{\circ} \mathrm{C}\right)\end{array}$ \\
\hline 9 & & $\begin{array}{c}\text { Mediterranean } \\
\text { Sea }\end{array}$ & $\begin{array}{l}\text { Cattolica, } \\
\text { Italy }\end{array}$ & N4358'14" E1244’21" & 34 & $15-23$ & $15(\mathrm{KI})$ & $\begin{array}{l}\text { Room temp } \\
\left(18-22^{\circ} \mathrm{C}\right)\end{array}$ \\
\hline 10 & & Red Sea & Gulf of Aqaba & N2931'58” E3458'18” & 34 & 23 & & \\
\hline 11 & & West Atlantic & $\begin{array}{l}\text { Woods Hole, } \\
\text { USA }\end{array}$ & $\mathrm{N} 41^{\circ} 31^{\prime} 34^{\prime \prime} \mathrm{W} 70^{\circ} 40^{\prime} 41^{\prime \prime}$ & 34 & $10-15$ & & \\
\hline 12 & & West Atlantic & $\begin{array}{c}\text { Ilha Grande, } \\
\text { Brazil }\end{array}$ & $\mathrm{S} 23^{\circ} 06^{\prime} 00^{\prime \prime} \mathrm{W} 44^{\circ} 10^{\prime} 22^{\prime \prime}$ & 34 & 23 & & \\
\hline 13 & & East Pacific & $\begin{array}{l}\text { Monterey, } \\
\text { USA }\end{array}$ & 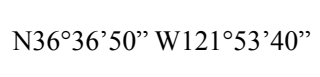 & 34 & $10-15$ & & \\
\hline 14 & & West Pacific & $\begin{array}{c}\text { Kagoshima Bay, } \\
\text { Japan }\end{array}$ & N3130’08” E130॰38’11” & 34 & 15 & 15 & $\begin{array}{c}\text { Room temp } \\
\left(18-22^{\circ} \mathrm{C}\right)\end{array}$ \\
\hline 15 & \multirow{2}{*}{ A. labiata } & East Pacific & $\begin{array}{c}\text { Friday Harbor, } \\
\text { USA }\end{array}$ & $\mathrm{N} 48^{\circ} 29^{\prime} 42^{\prime \prime} \mathrm{W} 123^{\circ} 00^{\prime} 03^{\prime \prime}$ & 34 & $10-15$ & & \\
\hline 16 & & East Pacific & $\begin{array}{c}\text { Coos Bay, } \\
\text { USA }\end{array}$ & $\mathrm{N} 43^{\circ} 23^{\prime} 00^{\prime \prime} \mathrm{W} 124^{\circ} 12^{\prime} 00^{\prime \prime}$ & 34 & $10-15$ & 10 & $\begin{array}{c}\text { Room temp } \\
\left(18-22^{\circ} \mathrm{C}\right)\end{array}$ \\
\hline 17 & A. limbata & $\begin{array}{c}\text { Sea of Okhotsk, } \\
\text { Pacific }\end{array}$ & Hokkaido, Japan & $\mathrm{N} 44^{\circ} 10^{\prime} 10^{\prime \prime} \mathrm{E} 144^{\circ} 20^{\prime} 20^{\prime \prime}$ & 34 & $10-15$ & & \\
\hline
\end{tabular}

culture 9 temperature was set from $23^{\circ} \mathrm{C}$ to $15^{\circ} \mathrm{C}$ and back to $23^{\circ} \mathrm{C}$ after 7 days. Three out of the seven cultures in which strobilation actually occurred were additionally treated with potassium iodine $(1.5 \mathrm{ml}$ KI in $100 \mathrm{ml}$ seawater; Spangenberg 1967, 1968) because the short-term temperature decrease was not sufficient to induce strobilation (Table 1). Scyphistomae and ephyrae were fed Artemia salina (Linné, 1758) nauplii once a week and every other day, respectively.

\section{Morphological and statistical analyses}

\section{Scyphistomae}

Scyphistomae were transferred to petri dishes and a 30-min period was allowed for them to relax and fully re-expand. Afterwards, individuals were digitally photographed and morphometric measurements were made using computer image analysis (ColorView, Soft Imaging System GmbH). Various morphological features were documented (colour, shape, number of tentacles) as well as strobilation duration and ephyrae production (Fig. 1). We took morphometric measurements as mentioned above following the method developed by Straehler-Pohl (2009), Straehler-Pohl \& Jarms (2010) and Straehler-Pohl et al. (2011). The morphometric measurements of scyphistomae were compared by using the following ratios (expressed in percent; abbreviations are explained in Table 2): CL/TBL; HL/TBL; StL/TBL; MDD/ TBL; CD0/CL; CD1/CL; CD2/CL; CD3/CL; StID/CL (for original data please refer to Appendix A). 


\section{Ephyrae}

Ephyrae were measured within $24 \mathrm{~h}$ after detachment. They were collected from petri dishes using a pipette and transferred with a small amount of water to a glass slide with the manubrium facing up, where they where allowed to relax for 5-10 minutes. They were photographed and measured as described above for scyphistomae, including differences in rhopalial lappet- and gastric canal forms (Fig. 1D). We took morphometric measurements as mentioned above following the method developed by Straehler-Pohl (2009), Straehler-Pohl \& Jarms (2010) and Straehler-Pohl et al. (2011). The morphometric measurements

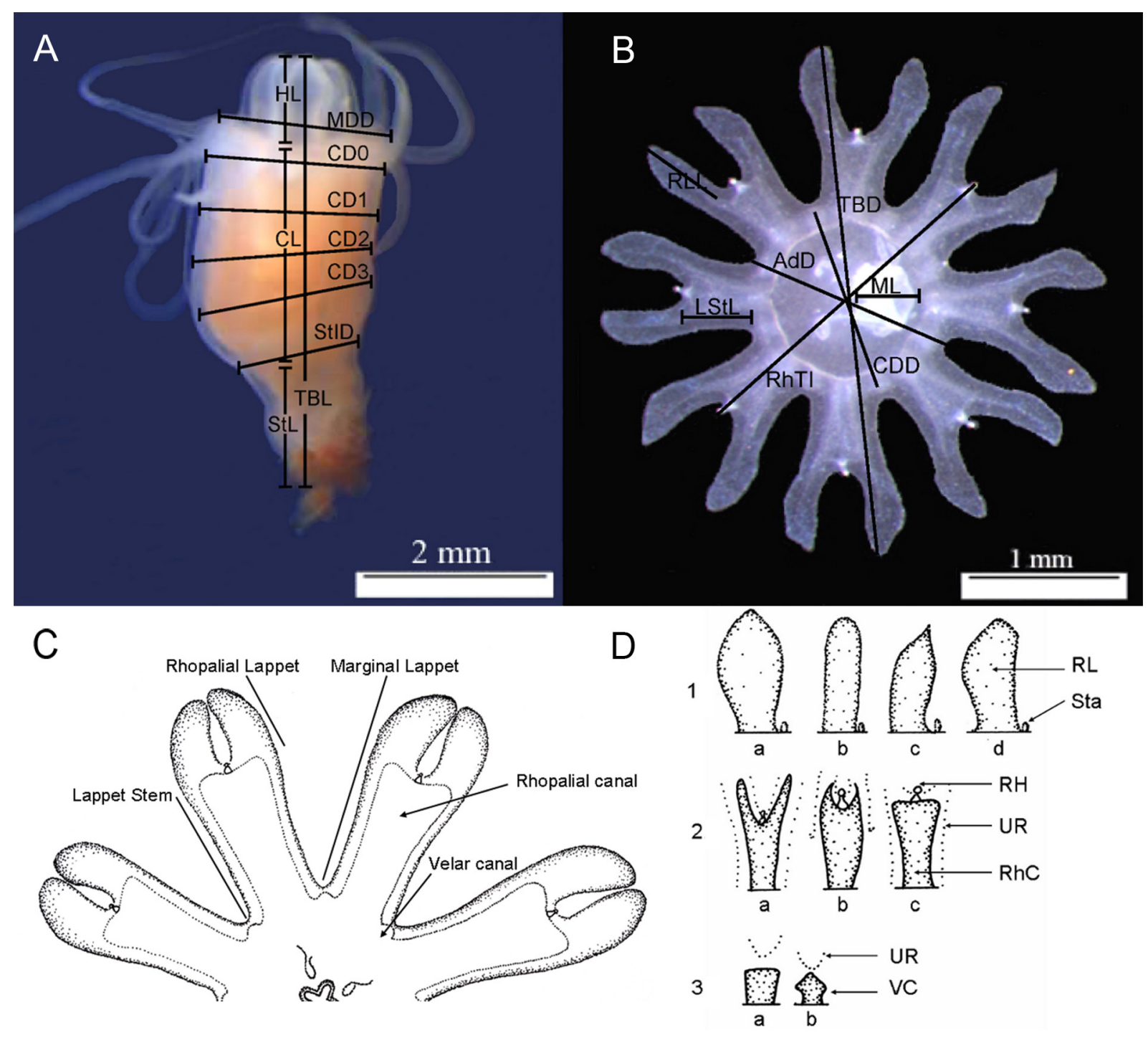

Fig. 1. Measurements of: A. Scyphistomae. B. Ephyrae. C. Lappets of an ephyra: the marginal lappet can be divided into rhopalial lappet and lappet stem; also visible are the rhopalial and velar canals. D. Rhopalial lappet and gastric canal forms of ephyrae in this study: 1. Rhopalial lappet forms (i.e. left lappet): (a) pointed spoon-like, (b) round spatula-like, (c) lancet-like and (d) bread knife-like; 2 . Rhopalial canal forms: (a) forked, sharp points, (b) club-shaped, forked, sharp points and (c) spade-like; $\mathbf{3}$. Velar canal forms: (a) spade-like and (b) rhombic. Abbreviations: $\mathrm{RH}=$ rhopalium; $\mathrm{RhC}=$ rhopalial canal; $\mathrm{RL}=$ rhopalial lappet; $\mathrm{Sta}=$ statolith; $\mathrm{UR}=$ umbrella rim; $\mathrm{VC}=$ velar canal. Other abbreviations: see Table 2. Modified after Straehler-Pohl \& Jarms (2010). 
Table 2. Measuring parameters for scyphistomae and ephyrae mainly according to Straehler-Pohl (2009), Straehler-Pohl \& Jarms (2010) and Straehler-Pohl et al. (2011).

\begin{tabular}{ll}
\hline \multicolumn{1}{c}{ Abbreviations for scyphistomae } & \multicolumn{1}{c}{ Actual measurement for scyphistomae } \\
\hline TBL (Total Body Length) & length from hypostome tip to basal disc \\
\hline CL (Calyx Length) & length from gastric cavity base to tentacle crown rim \\
\hline HL (Hypostome Length) & length from tentacle crown base to hypostome tip \\
\hline MDD (Mouth Disc Diameter) & widest diameter of mouth disc \\
\hline StL (Stalk Length) & length from basal disc to gastric cavity base \\
\hline CD0-3 (Calyx Diameter) & diameter of the calyx at four different areas \\
\hline StID (Stalk Initial Diameter) & diameter of the stalk at its beginning \\
\hline \multicolumn{1}{c}{ Abbreviations for ephyrae } & \multicolumn{1}{c}{ Actual measurements for ephyrae } \\
\hline TBD (Total Body Diameter) & 2x total length of marginal lappet + diameter of central disc \\
\hline CDD (Central Disc Diameter) & diameter of the central disc from the end of the gastric cavity \\
\hline TMLL (Total Marginal/Rhopalial Lappet & length of the lappet stem + length of rhopalial lappet \\
\hline Length) & $\begin{array}{l}\text { length from lappet base (line between the bases of two marginal lappet clefts) } \\
\text { to base of rhopalial niche (base of cleft between two rhopalial lappets) }\end{array}$ \\
\hline LStL (Lappet Stem Length) & length from rhopalial niche base to level of rhopalial lappet tips \\
\hline RLL (Rhopalial Lappet Length) & length between base and rim of manubrium \\
\hline ML (Manubrium Length) & adradial diameter of the central disc \\
\hline AdD (Adradial Diameter) & space between the rhopalar tips \\
\hline RhTI (Rhopalar Tip Interspace) & \\
\hline
\end{tabular}

of ephyrae were compared by using the following ratios (expressed in percent; abbreviations are given in Table 2): LStL/TMLL; RLL/TMLL; CDD/TBD; ML/TBD; RhTI/TBD; AdD/TBD; CDD/AdD; ML/ AdD; TMLL/TBD; LStL/TBD; RLL/TBD (for original data please see Appendix B).

We explored statistically significant differences between the 17 populations using a post-hoc, stepwise Linear Discriminant Analysis (LDA) of the ratios based on the morphometric measurements $(n=6$ individuals per population). Ephyra production and number of tentacles per scyphistoma (both $\mathrm{n}=10$ ) were evaluated using a Kruskal-Wallis test, followed by a Tukey's Honestly Significant Difference (HSD) post-hoc test. The significance level was set at alpha $<0.05$. Statistical analyses were performed using the software R 2.15.2 (R Core Team 2012).

\section{Results}

\section{Morphological analyses}

\section{Scyphistomae}

Scyphistomae of the 17 Aurelia populations were morphologically variable with respect to colour and shape of the calyx, the shape of the hypostome, and the number of tentacles (Table 3). We were able to distinguish four different calyx shapes (barrel, square, chalice, and cone) and four different hypostome shapes (convex, cap, cylindrical, and cone). The number of tentacles varied significantly among the populations (Kruskal-Wallis, $\mathrm{H}_{16}=67.3, \mathrm{p}>0.00001, \mathrm{n}=10$ ). Pairwise comparison revealed that population 12 (West Atlantic) was significantly different from all others (HSD, $\mathrm{p} \leq 0.05$ ). In 10 of the 17 populations there was a consistent ranking of body proportion (CL $>\mathrm{HL}>\mathrm{StL}$ ) and stalks in populations 4-6 (Baltic Sea and East Atlantic), 9 (Mediterranean Sea), 13 (East Pacific), 15 (East Pacific) and 16 (East Pacific) were longer than the hypostome (CL $>$ StL $>$ HL; Fig. 2). There were significant differences between ratios of hypostome length, calyx length and stem length in relation to 
Table 3. Collected morphological features of the scyphistomae of Aurelia sp.; tentacles were counted on 10 individuals

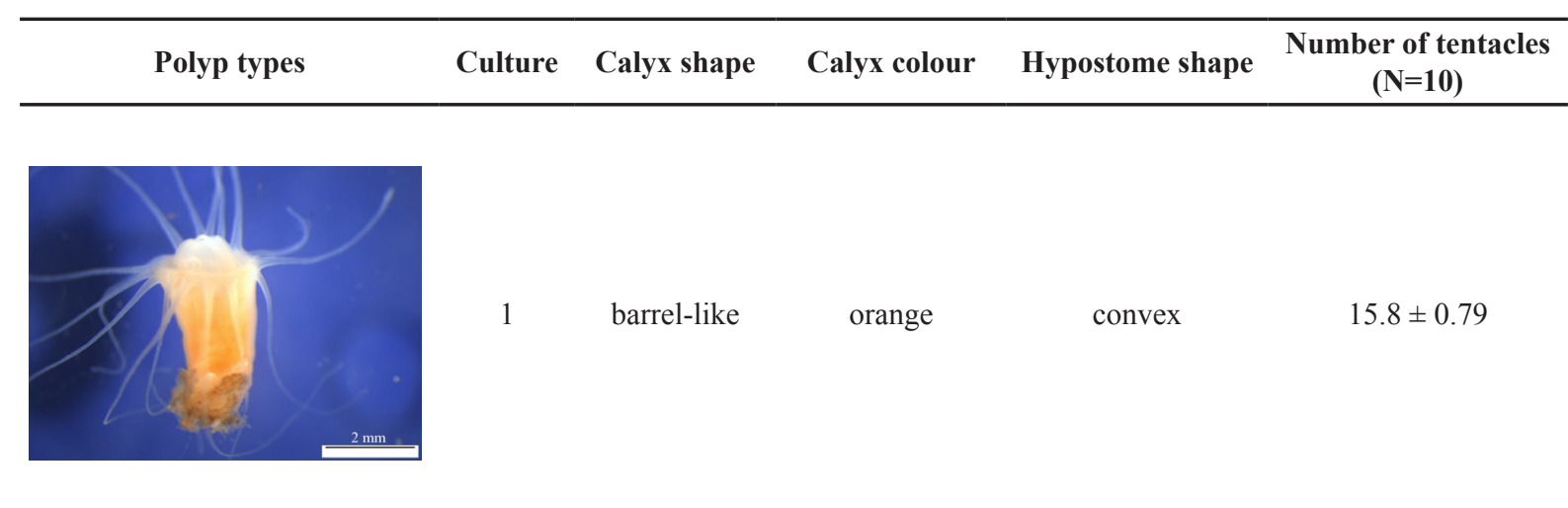
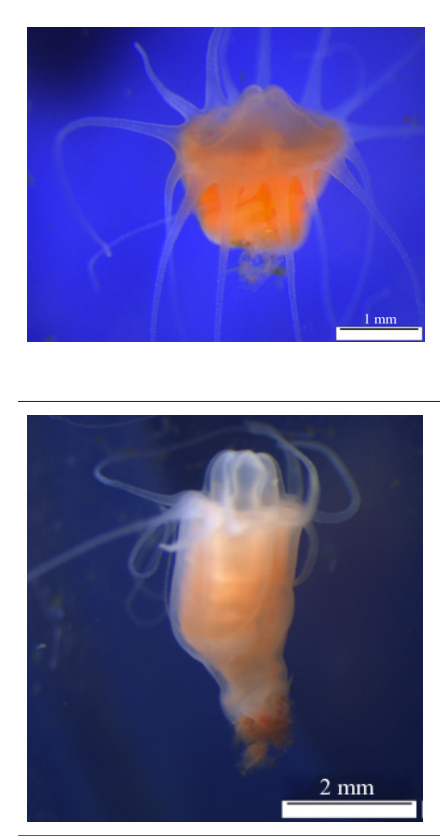

$3 \quad \begin{aligned} & \text { barrel-like, } \\ & \text { offset stalk }\end{aligned} \quad$ orange $\quad$ cylindrical $\quad 16.2 \pm 0.42$
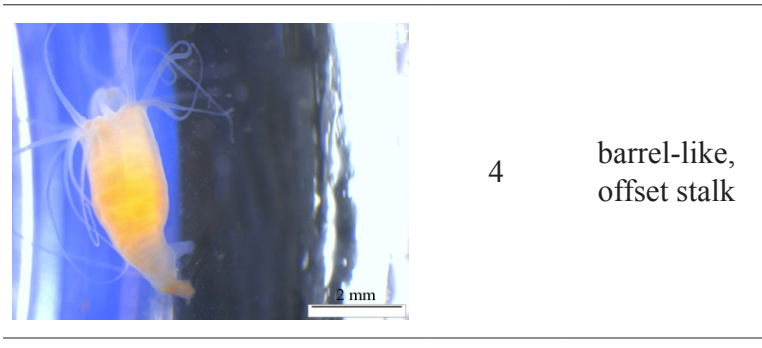
orange in the middle, rest milky white

cylindrical

$15.9 \pm 0.57$

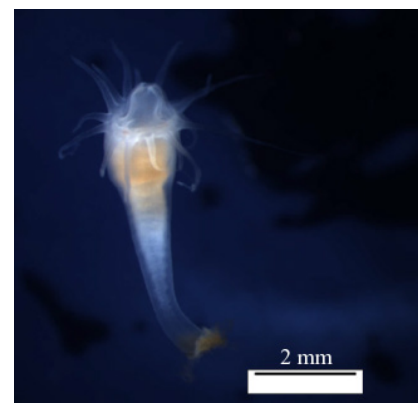

little orange in

cylindrical

$15.9 \pm 0.57$ the middle, rest milky white
5 chalice-like,
long stem


GAMBILL M. \& JARMS G., Comparison of different life stages of the genus Aurelia

\begin{tabular}{llllll}
\hline Polyp types & Culture & Calyx shape & Calyx colour & Hypostome shape $\begin{array}{c}\text { Number of tentacles } \\
(\mathbf{N}=10)\end{array}$ \\
\hline & & & & & \\
\hline
\end{tabular}

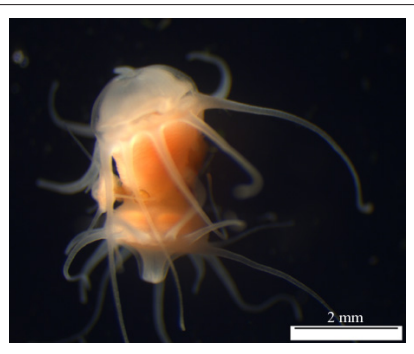
7
barrel-like
orange
convex
$15.5 \pm 0.71$

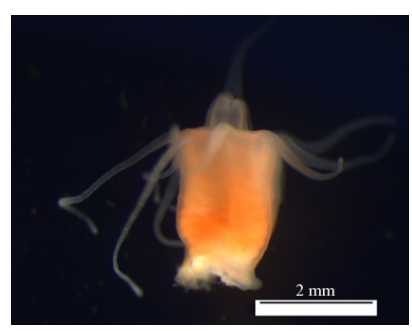

barrel-like

orange

cylindrical

$15.8 \pm 0.42$

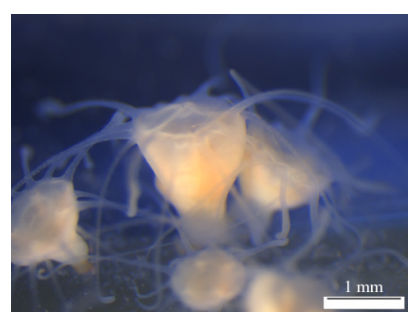

9

cone-like

milky white

cone-shaped

$16.2 \pm 0.42$

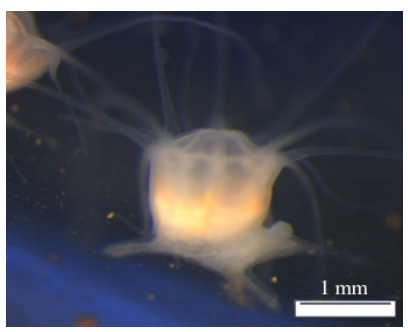

10

square

milky white

barely convex

$16.2 \pm 0.63$

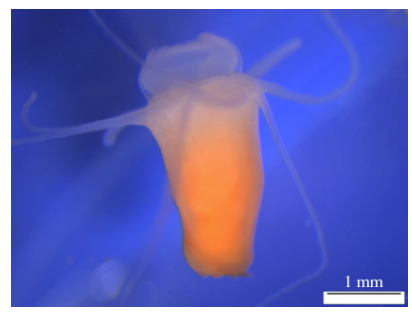



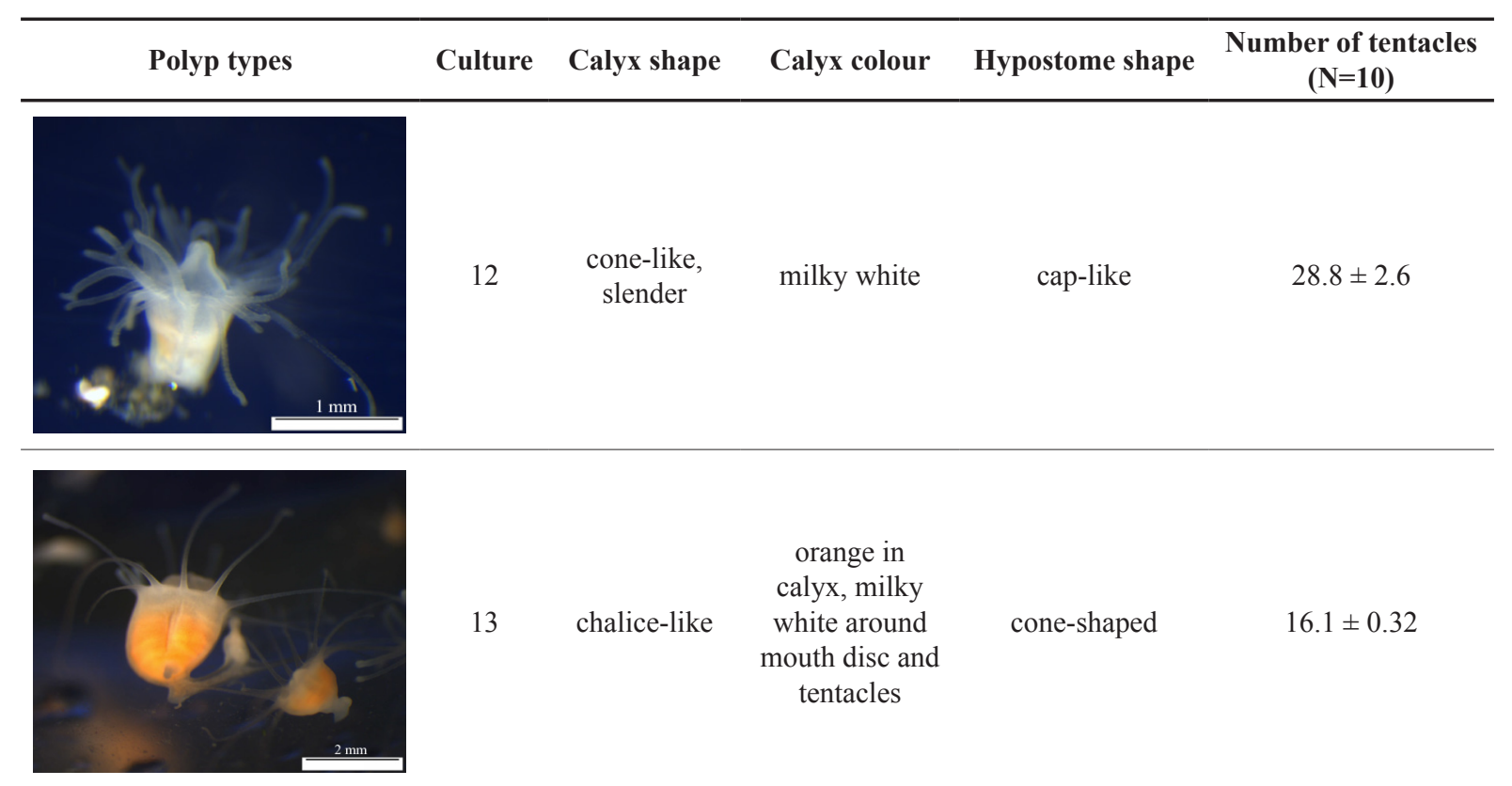

orange in calyx, milky

13 chalice-like white around

cone-shaped

$16.1 \pm 0.32$ mouth disc and tentacles

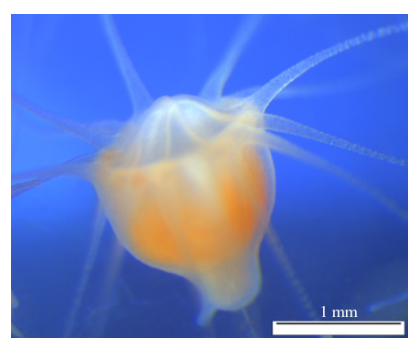

orange in

calyx, milky

14 chalice-like white around mouth disc and

cone-shaped

$16.0 \pm 0$ tentacles

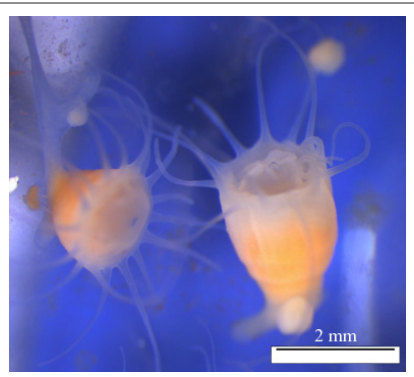

orange in calyx, milky

15 chalice-like white around

cone-shaped

$15.9 \pm 0.74$ mouth disc and tentacles
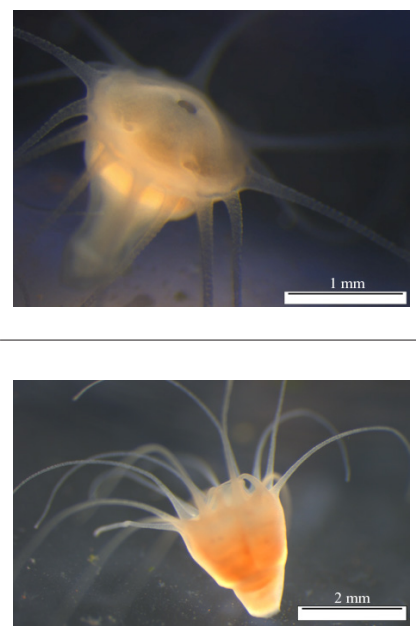

orange in calyx, milky 17 chalice-like white around mouth disc and

cylindrical $16.2 \pm 0.63$ 

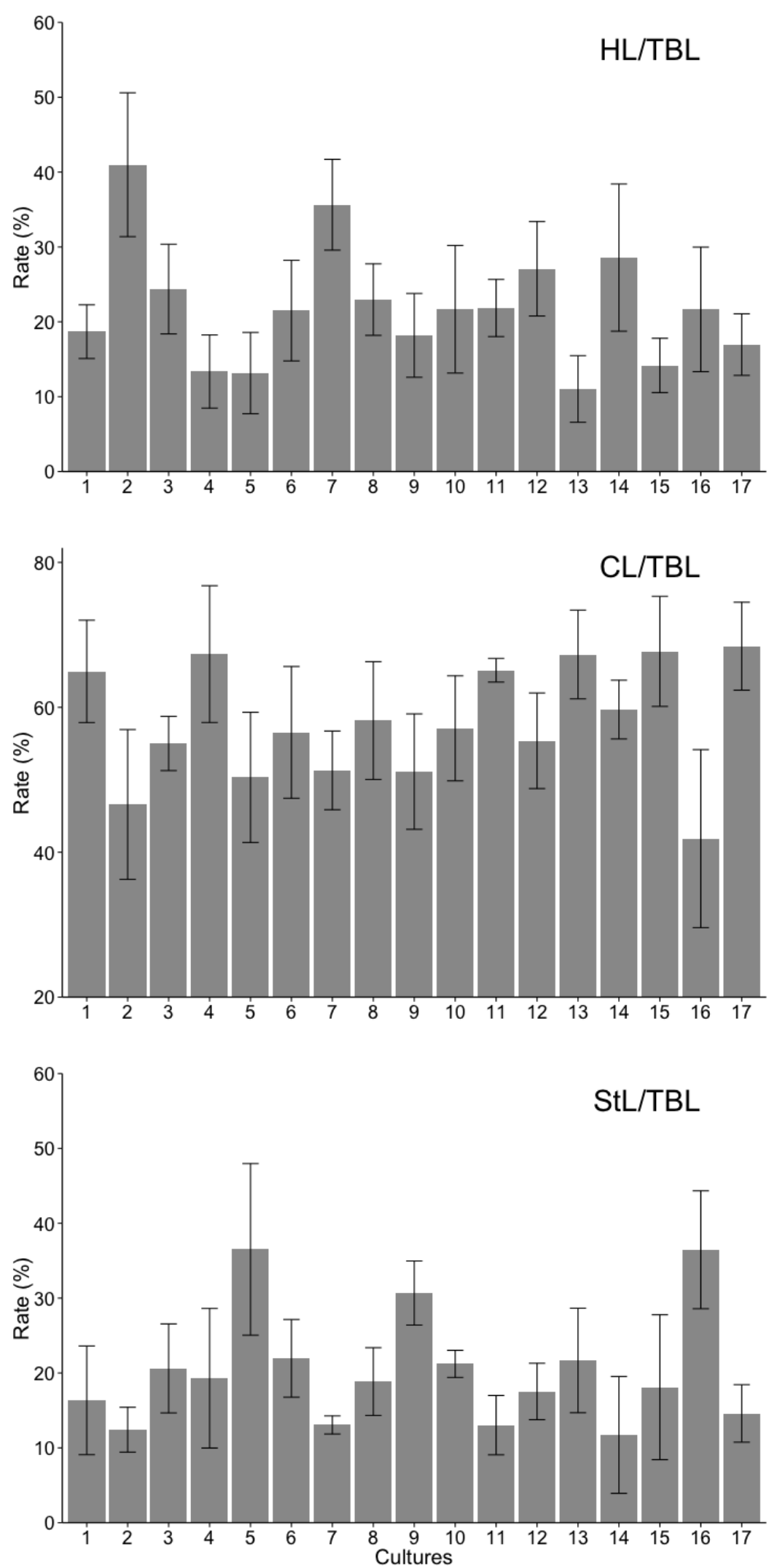

Fig. 2. Body proportions of polpys (shown as percentage). Error Bars show standard deviation. Abbreviations: see Table 2. 
Table 4. Analysis of Variances (ANOVA) for morphometric indices of scyphistomae and ephyrae. Abbreviations: $\mathrm{df}=$ degrees of freedom; $\mathrm{F}=\mathrm{F}-\mathrm{Ratio} ; \mathrm{p}=\mathrm{p}$-Value. Other abbreviations: see Table 2

\begin{tabular}{lcccc}
\hline \multicolumn{1}{c}{ Comparison of scyphistomae } & $\mathbf{d F}$ & $\mathbf{F}$ & $\mathbf{p}$ & $* * * *$ \\
\hline CL/TBL & 16,88 & 9.88 & $<0.001$ & $* * *$ \\
\hline HL/TBL & 16,88 & 9.87 & $<0.001$ & $* * *$ \\
\hline StL/TBL & 16,88 & 8.71 & $<0.001$ & $* * *$ \\
\hline \multicolumn{1}{c}{ Comparison of ephyrae } & $\mathbf{d F}$ & $\mathbf{F}$ & $\mathbf{p}$ & $* * *$ \\
\hline RLL/TBD & 6,35 & 16.17 & $<0.001$ & $* * *$ \\
\hline ML/TBD & 6,35 & 6.98 & $<0.001$ & $* * *$ \\
\hline TMLL/TBD & 6,35 & 24.73 & $<0.001$ & $* * *$ \\
\hline LStL/TBD & 6,35 & 26.70 & $<0.001$ & $* * *$ \\
\hline CDD/TBD & 6,35 & 39.63 & $<0.001$ & $* * *$ \\
\hline RLL/TMLL & 6,35 & 16.87 & $<0.001$ & $* * *$ \\
\hline LStL/TMLL & 6,35 & 16.87 & $<0.001$ & $* * *$ \\
\hline RhTI/TBD & 6,35 & 8.69 & $<0.001$ & $* * *$ \\
\hline
\end{tabular}

total body length of scyphistomae (ANOVA, $p<0.001$, Fig. 2, Table 4). Most of the scyphistomae had 14 to 17 tentacles except cultures 15 and 16 (14 to 16 ) and culture 12 (27 to 33 ).

\section{Strobilation}

Strobilation occurred in 7 of the 17 populations (Tables 1, 5). In cultures 1 (North Sea) and 16 (East Pacific), scyphistomae strobilated after a decrease in temperature. In cultures 2 (North Sea), 8 (North Sea / Skagerrak) and 9 (Mediterranean Sea), strobilation commenced after exposure to KI and a decrease in temperature. Cultures 6 (East Atlantic) and 14 (Pacific) were maintained at $15^{\circ} \mathrm{C}$ and strobilated several times. The strobilation process from the development of the first constriction until detachment of the last ephyra lasted 17 to 27 days. In six of seven cultures, at least ten scyphistomae strobilated. Only 1 scyphistoma strobilated in culture 1 (North Sea) and this culture was not included in further analyses concerning the strobilation process. Cultures from the Pacific Ocean (cultures 14 and 16) had much shorter strobilation times (17 to 18 days) compared to the four cultures from the East Atlantic Ocean / North Sea (cultures 1, 2, 6 and 8) and the Mediterranean (culture 9). In these six cultures (i.e., excluding culture 1), the mean ( \pm standard deviation) number of ephyrae per strobila varied from $6.0 \pm 0.9$ to $21.1 \pm 3.0$ and was significantly different among cultures (Kruskal-Wallis H5 $=47.4, \mathrm{p}<0.001, \mathrm{n}=10$ ). The number of ephyrae per strobila in the Pacific cultures was significantly lower than that of the remaining experimental cultures (HSD, $\mathrm{p} \leq 0.05$ ).

\section{Ephyrae}

The colour of the ephyrae ranged from translucent white to translucent pink to reddish brown (Table 5). The shape of the rhopalial lappets as well as the shapes of the rhopalial and velar canals differed between cultures (Table 5). Lappet proportions of the ephyrae exhibited differences. Culture 6 (East Atlantic) produced ephyrae showing ratios of rhopalial lappet (RLL) to lappet stem length (LStL) of almost $60 \%$ whereas others were about 50\% (Fig. 3). A factorial ANOVA revealed significant differences of body proportions between all species ( $\mathrm{p}<0.001$, Fig. 3, Table 4). 
Table 5. Collected morphological features of the ephyrae of Aurelia sp.

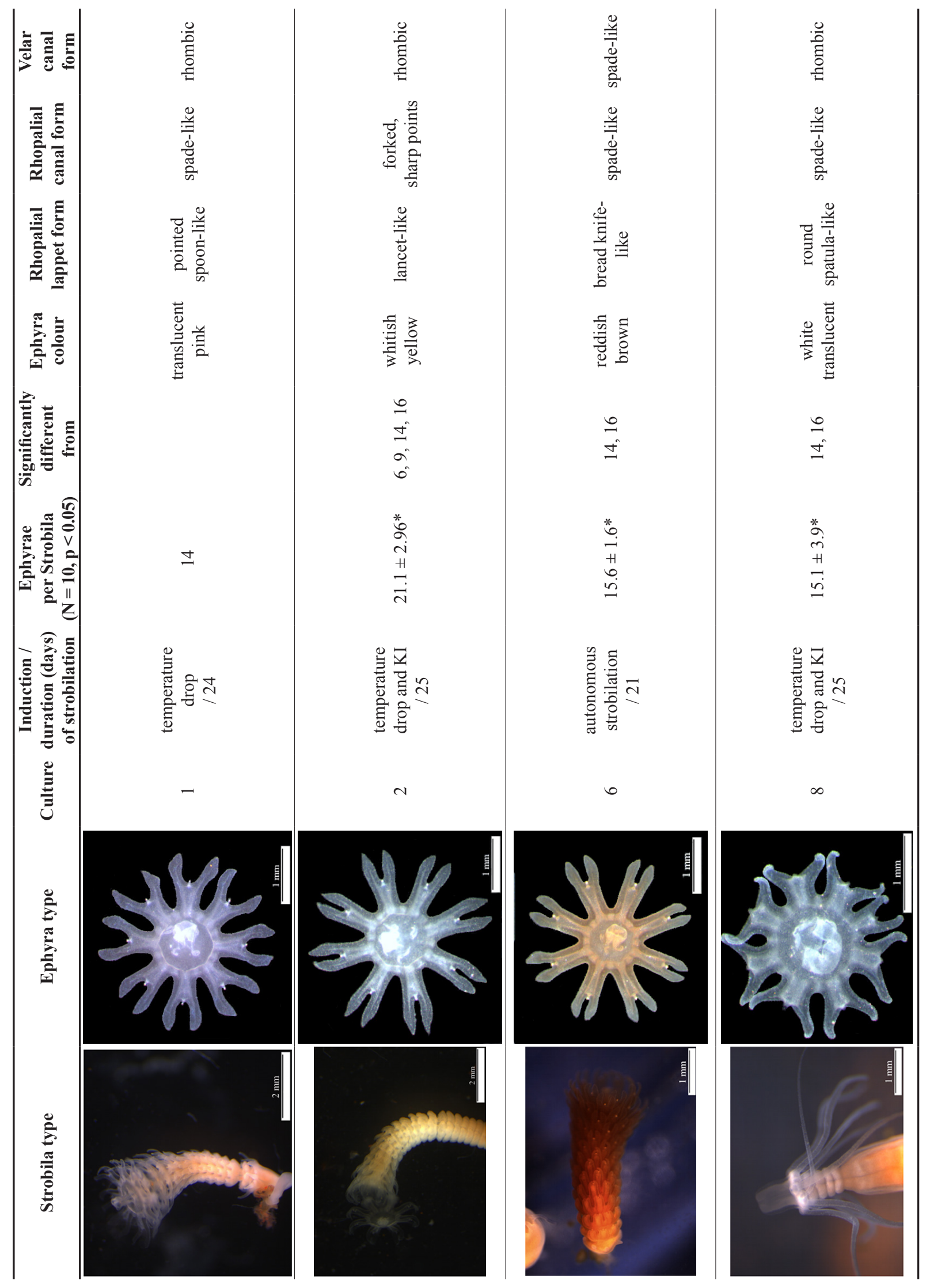




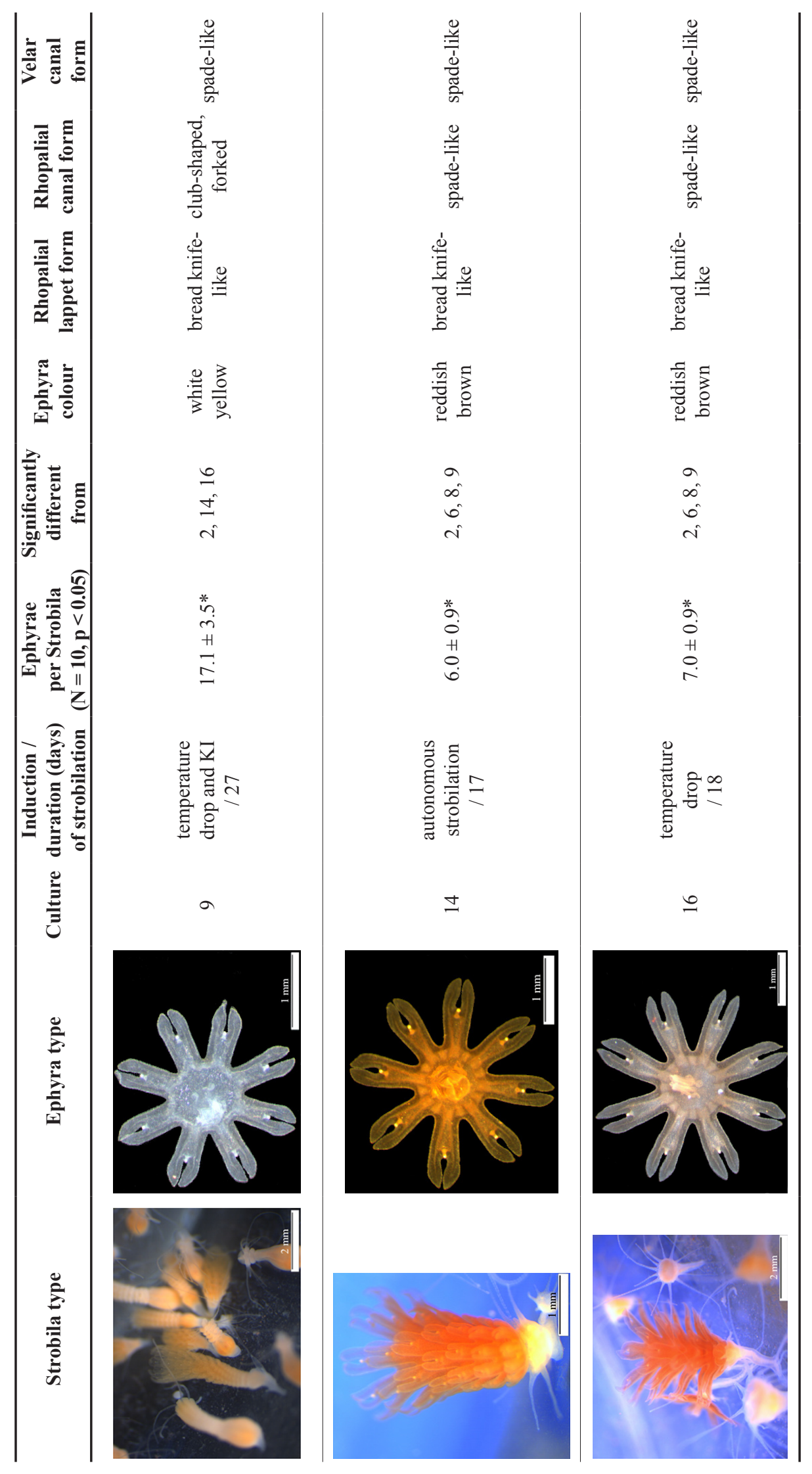



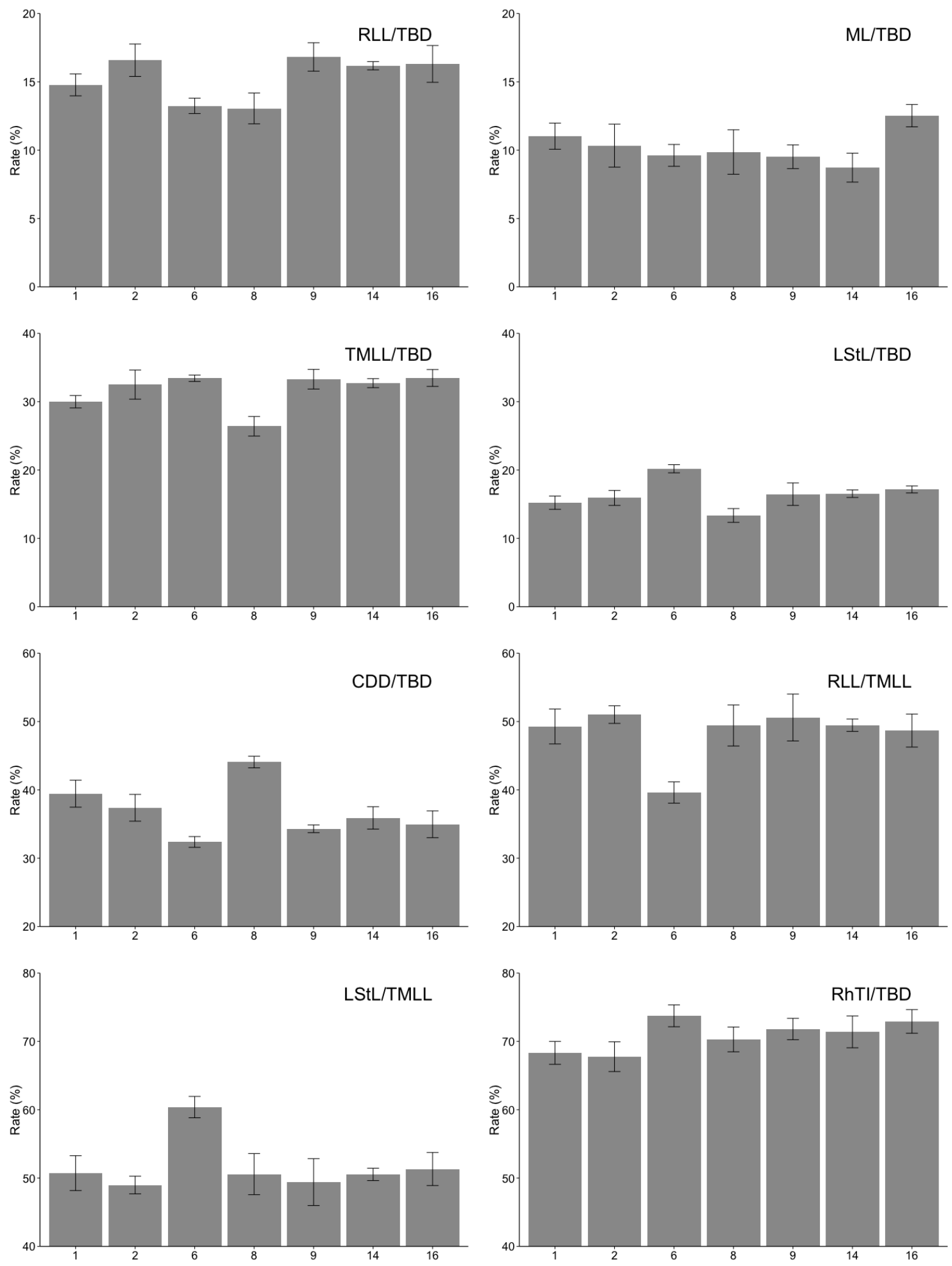

Fig. 3. Body proportions of ephyrae (shown as percentages). Error bars show standard deviation. Abbreviations: see Table 2. 


\section{Linear Discriminant Analysis (LDA)}

\section{Scyphistomae}

The LDA based on ratios of morphometric measurements for scyphistomae did not identify any kind of separation among the 17 populations. All populations overlapped to varying degrees except for populations 2 (North Sea) and 16 (East Pacific; Fig. 4A).

\section{Ephyrae}

The LDA based on ratios of morphometric measurements for ephyrae suggested distinct classifications (Fig. 4B) with overlaps between populations 9 (Mediterranean Sea) and 14 (Pacific), 1 and 2 (North Sea), and a similar placement of populations 16 (East Pacific) and 9 (Mediterranean Sea). Ephyrae from populations 6 (East Atlantic) and 8 (North Sea / Skagerrak) were completely isolated from each other and from the other populations.

\section{Discussion}

Some morphological features of scyphistomae and ephyrae can be used to distinguish congeners while others cannot. Straehler-Pohl \& Jarms (2010) reported that the relation between rhoparlar lappet length (RLL) and lappet stem length (LStL) and the development of the gastric system could be important distinguishing features of genera but not species. Aurelia aurita from the North Sea has rhopalial (forked, sharp points) and velar canals (rhombic) as well as lancet-like rhopalial lappets (Straehler-Pohl \& Jarms 2010; Straehler-Pohl et al. 2011; Holst 2012b), which match ephyrae from population 2. In this study, ephyrae have four different rhopalial lappet shapes, three different rhopalial canal shapes and two different velar canal shapes, which supports the genetic evidence suggesting more than three species within Aurelia (Dawson \& Jacobs 2001; Dawson \& Martin 2001; Schroth et al. 2002). Although colour is another trait that depends on a variety of factors, when maintained on the same diet (Artemia nauplii),

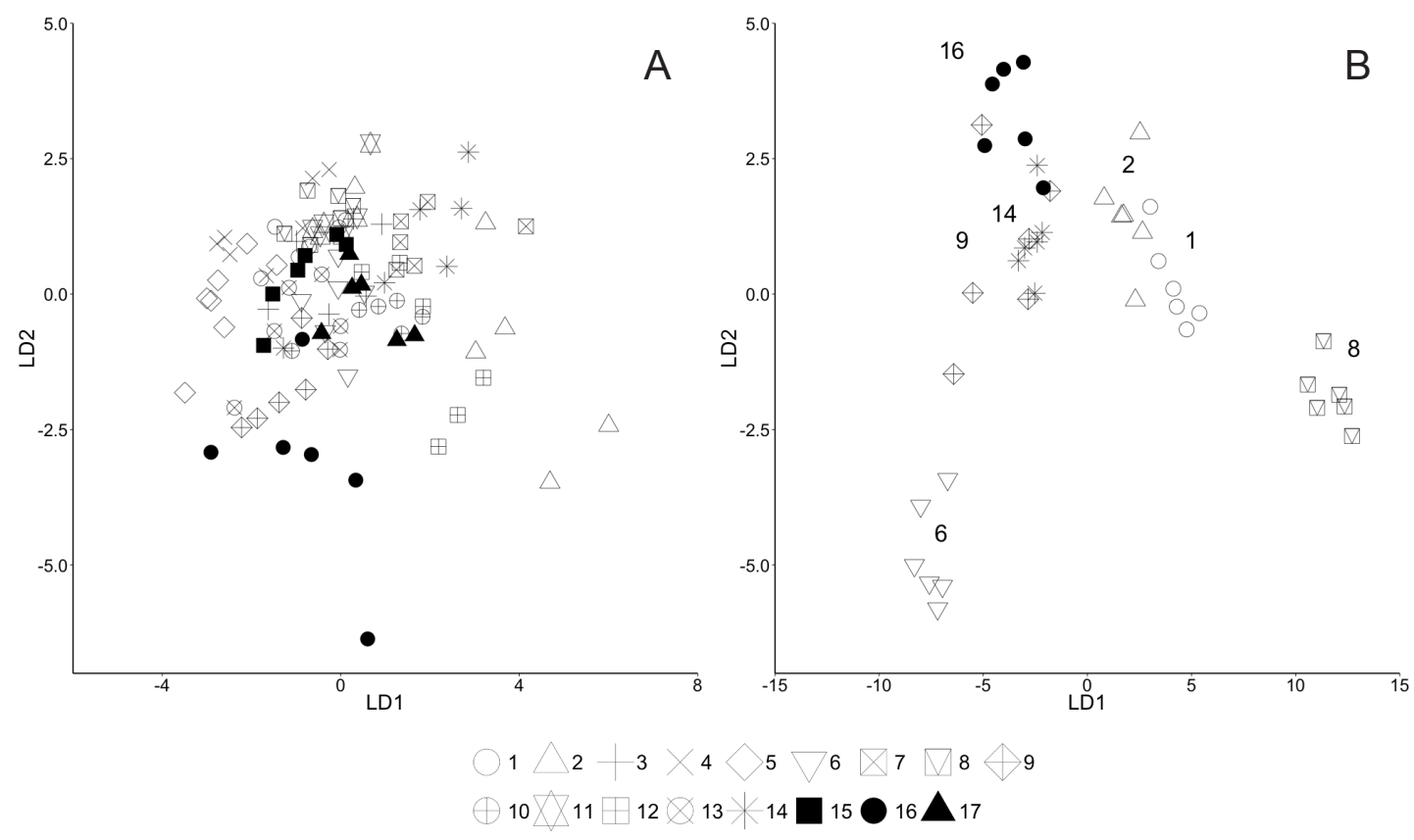

Fig. 4. Linear Discriminant Analysis based on the morphology. A. Scyphistomae (17 cultures) of Aurelia congeners. B. Ephyrae ( 7 of the 17 cultures) of Aurelia congeners. In each case, cultures can be distinguished from one another by different symbols and corresponding numbers (see legend). 
higher latitude scyphistomae produce white and translucent ephyrae and the degree of pigmentation increased with decreasing latitude. Moreover, ephyrae produced by Pacific scyphistomae differed in colour from those produced by scyphistomae collected from the Atlantic Ocean and Mediterranean Sea. Therefore, colour can be a useful trait if compared among individuals maintained using the same culture/feeding conditions.

The LDA we conducted using the morphometric data of ephyrae reveal a clear separation of the different populations (Fig. 4b), which again supports the genetically indicated existence of more than three species. The obvious partitioning clearly allows classifications to be made and these are discussed (below) in light of known differences among the 17 populations.

In scyphistomae the colour of the calyx was not a reliable characteristic to differentiate among species, since it was more or less the same in all scyphistomae. We expected differences similar to the ones found in ephyrae, due to the same feeding conditions (Straehler-Pohl 2009; Straehler-Pohl \& Jarms 2010; Holst 2012b). The shape of the calyx was a suitable character for separating species (e.g., a cup-like calyx is characteristic of A. limbata [Straehler-Pohl 2009; this study]), although the morphology of the calyx and hypostome can vary and can be misinterpreted (Berrill 1949; Straehler-Pohl 2009; Straehler-Pohl et al. 2011). Moreover, biotic and abiotic factors such as food intake, light intensity, salinity and temperature may affect the shape and colour of these features (Spangenberg 1964; Willcox et al. 2007). The number of tentacles is an obvious morphological feature of scyphistomae which also displays interspecific variability, with A. aurita and A. labiata having 14 to 28 (Holst 2008; Straehler-Pohl 2009; this study) and 14 to 21 (Gershwin 2001; Widmer 2006; this study), respectively. Scyphistomae of population 12 had between 27 and 33 tentacles and, based on this morphology, may not belong to Aurelia. Finally, the length of the hypostome in relation to the stem has been reported to distinguish members of Scyphozoa (Semaeostomeae: CL > HL > StL, Cepheida: StL > CL > HL, Rhizostomida: CL > StL > HL; StraehlerPohl 2009; Straehler-Pohl et al. 2011). In this study, StL was $>$ HL in only $40 \%$ of the specimens; this relationship is not suitable for distinguishing Aurelia congeners. Furthermore, we demonstrate that morphometric measurements of scyphistomae cannot be used to distinguish among species within this genus (Fig. 4A).

Lucas et al. (2012) provide a review of studies conducted on scyphistoma populations, including the species-specific triggers for strobilation. We were able to induce strobilation in 7 of the 17 populations using cues known to be effective for Aurelia species, including a decrease in temperature and, in some cases, the addition of KI (Berrill 1949; Spangenberg 1967; see Lucas et al. 2012). Spangenberg (1964) discovered that scyphistomae with large calices produce more ephyrae than small scyphistomae and still have enough energy to regenerate the residuum (Straehler-Pohl \& Jarms 2005). Scyphistomae are often larger when grown at low salinities and low temperatures (Schroth et al. 2002; Willcox et al. 2007) and could therefore produce more ephyrae than smaller scyphistomae in warmer waters, possibly due to higher availability of tissue. Our results suggested longer durations of strobilation and greater numbers of ephyrae produced by scyphistomae collected from higher (colder) versus lower (warmer) latitudes despite scyphistomae being maintained at the same temperature in the laboratory, even though some populations needed the temperature drop and the consequent rise to start the strobilation process. Naturally, the number of ephyrae produced by scyphistomae depends upon both endogenous and exogenous factors (Lucas et al. 2012) and the effect of the latter make it difficult to use this trait to differentiate species within one genus.

\section{Classification}

Historical reports and descriptions of species within Aurelia often used geographical distribution as a distinguishing characteristic. However, geographical distributions of many planktonic organisms have changed via transport in ballast waters and jellyfish introductions are commonly reported (Greenberg 
et al. 1996; Purcell et al. 2007). The potential for mixing of different (potentially cryptic) species within the same area demands that methods be found to reliably identify species. In the following, we discuss the 17 populations in terms of the results of our morphological observations of scyphistomae and ephyrae, morphometric measurements of ephyrae, recent genetic analyses as well as information on geographical distribution.

\section{Group 1}

Populations 1-5, 7, 8: Agreement - A. aurita. All of these scyphistomae were collected from eastern parts of the Atlantic Ocean and the Baltic Sea. Molecular (Dawson \& Jacobs 2001; Schroth et al. 2002; Dawson et al. 2005), distributional (Mayer 1910, 1917; Kramp 1961; Russell 1970) and our data as described in Table 3 support this species identification for populations 1-5, 7 and 8 . The effects of changes in salinity on the morphological characteristics of scyphistomae and ephyrae are not known and could influence classification based merely on morphology. However, morphometric measurements of ephyrae (see Table 5) suggested that population 8 was morphologically distinct from populations 1 and 2. We speculate that populations 1 and 8 may be boreal species as suggested by Schroth et al. (2002). The results of the LDA suggest that population 8 may be transitional between North Sea and Atlantic populations, which is supported by the findings of Dawson et al. (2005). Group 1 is considered to be a member to the initially described species, Aurelia aurita (Table 6).

\section{Group 2}

Population 6: Disagreement - Aurelia aurita which is likely another species. Scyphistomae in populations 6, 9 and 10 originated from geographically separate areas (North Sea, the Atlantic Ocean and Red Sea, respectively); nevertheless their scyphistomae and ephyrae share some common morphological characteristics (see Tables 3, 5). Unlike the genetic analyses reported by Schroth et al. (2002), our morphometric measurements distinguish population 6 from all the other groups. Dawson \& Jacobs (2001) as well as Schroth et al. (2002) propose populations 6 and 14 to be the same species, and geographic differences may not be valid given ballast water transport of conspecifics. Still, based on the literature (Mayer 1910, 1917; Kramp 1961; Russell 1970) and our measurements, we suggest that population 6 represents the only member of group 2 and a new species, Aurelia sp. 1 (Table 6).

\section{Group 3}

Population 9: Disagreement $-A$. aurita which is likely another species. Animals from culture 9 were collected in the Mediterranean Sea and the separation into a new species is supported by genetic uniqueness (Dawson \& Jacobs 2001; Dawson \& Martin 2001; Schroth et al. 2002, Dawson et al. 2005). Also, the morphology of the ephyrae shows unique features, e.g., the yellowish colour in combination with the shape of the lappets and the shapes of rhopalial- and velar canals. Nonetheless, population 9 displays similar morphological features to A. aurita (Kramp 1961). Schroth et al. (2002) suggested a transitional habitat called "Tethys," which includes populations in the Mediterranean and Red Seas. We therefore provisionally place culture 9 within the taxon Aurelia cruciata Haeckel, 1880 (Mayer 1910; Kramp 1961) as it is located within the "Tethys" habitat.

\section{Group 4}

Population 10: Disagreement $-A$. aurita which is likely another species. Animals from population 10 were collected from the Gulf of Aqaba, also within this "Tethys" region defined by Schroth et al. (2002) and Dawson et al. (2005). Individuals display a similar morphology to A. aurita (Kramp 1961). We suggest placing population 10 within the taxon Aurelia maldivensis Bigelow, 1904 (Stiansy 1938; Kramp 1961) considering its range of distribution within the "Tethys" habitat (see Table 6). 
Table 6. Classification of the different populations (cultures 1-17) into eight different groups/species based on our results (morphological and statistical: Linear Discriminant Analysis [LDA]) under consideration of the literature (genetic and distributional data).

\begin{tabular}{|c|c|c|c|c|c|}
\hline Culture & Origin & $\begin{array}{c}\text { Proposed species } \\
\text { (a priori) } \\
\end{array}$ & $\begin{array}{c}\text { Was it the } \\
\text { proposed species? }\end{array}$ & Suggested species & Group \\
\hline 1 & North Sea & \multirow{14}{*}{ Aurelia aurita } & yes & Aurelia aurita & 1 \\
\hline 2 & North Sea & & yes & Aurelia aurita & 1 \\
\hline 3 & North Sea & & yes & Aurelia aurita & 1 \\
\hline 4 & Baltic Sea & & yes & Aurelia aurita & 1 \\
\hline 5 & Baltic Sea & & yes & Aurelia aurita & 1 \\
\hline 6 & East Atlantic & & no & Aurelia sp. 1 & 2 \\
\hline 7 & Arctic Ocean & & yes & Aurelia aurita & 1 \\
\hline 8 & East Atlantic & & yes & Aurelia aurita & 1 \\
\hline 9 & Mediterranean Sea & & no & Aurelia cruciata & 3 \\
\hline 10 & Red Sea & & no & Aurelia maldivensis & 4 \\
\hline 11 & West Atlantic & & no & Aurelia flavidula & 5 \\
\hline 12 & West Atlantic & & no & Aurelia sp. 2 & 6 \\
\hline 13 & East Pacific & & no & Aurelia labiata & 7 \\
\hline 14 & Pacific & & no & Aurelia labiata & 7 \\
\hline 15 & East Pacific & \multirow{2}{*}{ Aurelia labiata } & yes & Aurelia labiata & 7 \\
\hline 16 & East Pacific & & yes & Aurelia labiata & 7 \\
\hline 17 & Pacific & Aurelia limbata & yes & Aurelia limbata & 8 \\
\hline
\end{tabular}

\section{Group 5}

Population 11: Disagreement - Aurelia aurita which is likely another, transitional species. Based on known distributions of adult medusae (given the caveats of potential mixing) and morphological features (Table 5), population 11 can be separated from the other Atlantic populations of A. aurita. This population is possibly a member of the taxon Aurelia flavidula Péron \& Lesueur, 1809 (Péron \& Lesueur 1809; Mayer 1910; Kramp 1961) or Aurelia marginalis Agassiz, 1862 (Mayer 1910). Classification into a different taxon seems reasonable at this point, even though these findings are not yet supported by molecular data.

\section{Group 6}

Population 12: Disagreement $-A$. aurita which is likely another species. Collected from Brazilian waters, the morphology of scyphistomae (27-33 tentacles) of population 12 differs from all other populations. The shape of the calyx in combination with the cap-like hypostome, as well as the very small size of the scyphistomae, suggest differences from the other populations. Dawson \& Jacobs (2001) found an Aurelia species on the east coast of South America that also has a unique morphology. Mayer (1910) described individuals off the Brazilian coast as A. aurita. Either there have been some misclassifications or both 
species coexist in this area. Based on the results of this study and the currently available literature, we suggest this population to be a separate species, which we call Aurelia sp. 2.

\section{Group 7}

Populations 13-16: Agreement - A. labiata. Both genetic analyses and morphological observations of scyphistomae, strobilae and ephyrae and morphometric measurements in ephyrae correctly distinguished populations 13-16 as A. labiata (Gershwin 2001; Dawson \& Jacobs 2001; Dawson et al. 2005; Widmer 2005). The genetic relationship between populations 16 and 6 as reported by Schroth et al. (2002) cannot be substantiated. Genetic analyses classify US west coast populations of Aurelia as A. labiata (Dawson \& Jacobs 2001; Dawson \& Martin 2001; Schroth et al. 2002) and the morphology of both ephyrae and adult medusae (Mayer 1910; Gershwin 2001; Dawson 2003; Widmer 2005) support this classification. Nevertheless, differences in morphology and life cycle suggest that southern, central and northern varieties exist (Gershwin 2001) or that these may represent different species (Dawson 2003).

\section{Group 8}

Population 17: Agreement - A. limbata. Our morphological observations of these scyphistomae match those previously made by Uchida \& Nagao (1963) and the species is confirmed by both morphological (Kramp 1961) and genetic features (Dawson \& Martin 2001; Schoth et al. 2002, Dawson et al. 2005) of medusae. Aurelia limbata is found in the Northwest and Northeast Pacific, northern Japan, Western Greenland, Alaska, Labrador and Siberia (Mayer 1910; Bigelow 1913; Uchida 1934; Kramp 1961).

\section{Conclusion}

We provide a detailed morphological dataset for the scyphistomae of 17 populations of Aurelia congeners. Morphometric characteristics of ephyrae from 7 populations were good indicators of different species/ groups; still, morphometric data of scyphistomae collected and processed by the method of StraehlerPohl (2009), Straehler-Pohl \& Jarms (2010) and Straehler-Pohl et al. (2011) where not separative in order to distinguish among Aurelia species. Based on morphological differences (this study), genetic differences (Dawson \& Jacobs 2001; Dawson \& Martin 2001; Schroth et al. 2002; Dawson 2003; Dawson et al. 2005) and differences in geographical distribution (Mayer 1910; Kramp 1961; Russell 1970; Gershwin 2001; Widmer 2005), we suggest a separation of these 17 populations, which would include 8 groups: A. aurita, A. labiata, A. limbata, two new Aurelia spp., and three formerly recognized species. Our assessments agree with the a priori species assignments for 10 of the 17 populations. This is another step towards understanding the complexity of the genus Aurelia and it reveals the importance of considering the whole cnidarian life cycle, particularly differences in asexual propagation and morphological characteristics of ephyrae, when attempting to distinguish species.

\section{Acknowledgements}

We would like to thank Prof. Myron A. Peck for helpful comments on drafts of this manuscript. The research leading to these results has received partial funding from the European Community's Seventh Framework Program (FP7/2007-2013) under Grant Agreement No. 266445 for the project Vectors of Change in Oceans and Seas Marine Life, Impact on Economic Sectors (VECTORS). The experiments performed comply with the current laws of Germany.

\section{References}

Adler L. \& Jarms G. 2009. New insights into reproductive traits of scyphozoans: special methods of propagation in Sanderia malayensis GOETTE, 1886 (Pelagiidae, Semaeostomeae) enable establishing a new classification of asexual reproduction in the class Scyphozoa. Marine Biology 156 (7): 1411-1420. http://dx.doi.org/10.1007/s00227-009-1181-6 
GAMBILL M. \& JARMS G., Comparison of different life stages of the genus Aurelia

Albert D.J. 2005. Reproduction and longevity of Aurelia labiata in Roscoe Bay, a small bay on the Pacific coast of Canada. Journal of the Marine Biological Association of the United Kingdom 85 (3): 575-581. http://dx.doi.org/10.1017/S0025315405011501

Berrill N.J. 1949. Form and growth in the development of a scyphomedusa. Biological Bulletin 96 (3): 283-292. http://dx.doi.org/10.2307/1538363

Bigelow H.B. 1904. Medusae from the Maldive Islands. Bulletin of the Museum of Comparative Zoology, Harvard 39 (9): 261-262.

Bigelow H.B. 1913. Medusae and siphonophorae collected by the U.S. Fisheries Steamer Albatross in the north-west Pacific, 1906. Proceedings of the United States National Museum 44: 1-119. http:// dx.doi.org/10.5479/si.00963801.44-1946.1

Brandt J.F. 1838. Ausführliche Beschreibung der von $\mathrm{CH}$ Mertens auf seiner Weltumsegelung beobachteten Schirmquallen nebst allgemeinen Bemerkungen über die Schirmquallen überhaupt. Mémoires de l'Académie impériale des Sciences de St.-Pétersbourg. sér. 6. Sciences naturelles 2: 237 411.

Chamisso A. de \& Eysenhardt C.G. 1820. De animalibus quibusdam e classe vermium Linneana (18151818). Nova Acta Academiae Caesareae Leopoldino-Carolinae Germanicae Naturae Curiosorum 10 (2): 345-374

Condon R.H., Decker M.B. \& Purcell J.E. 2001. Effects of low dissolved oxygen on survival and asexual reproduction of scyphozoan polyps (Chrysaora quinquecirrha). Hydrobiologia 451: 89-95. http://dx.doi.org/10.1023/A:1011892107211

Condon R.H., Graham W.M., Duarte C.M., Pitt K.A., Lucas C.H., Haddock S.H., Sutherland K.R., Robinson K.L., Dawson M.N., Decker M.B., Mills C.E., Purcell J.E., Malej A., Mianzan H., Uye S.I., Gelcich S. \& Madin L.P. 2012. Questioning the Rise of Gelatinous Zooplankton in the World's Oceans. BioScience 62 (2): 160-169. http://dx.doi.org/10.1525/bio.2012.62.2.9

Condon R.H., Duarte C.M., Pitt K.A., Robinson K.L., Lucas C.H., Sutherland K.R., Mianzan H.W., Bogeberg M., Purcell J.E., Decker M.B., Uye S.I., Madin L.P., Brodeur R.D., Haddock S.H.D., Malej A., Parry G.D., Eriksen E., Quiñones J., Acha M., Harvey M., Arthur J.M. \& Graham W.M. 2013. Recurrent jellyfish blooms are a consequence of global oscillations. Proceedings of the National Academy of Sciences 110 (3): 1000-1005. http://dx.doi.org/10.1073/pnas.1210920110

Dawson M.N. 2003. Macro-morphological variation among cryptic species of the moon jellyfish, Aurelia (Cnidaria: Scyphozoa). Marine Biology 143 (2): 369-379. http://dx.doi.org/10.1007/s00227-003-1070-3

Dawson M.N. \& Jacobs D.K. 2001. Molecular Evidence for Cryptic Species of Aurelia aurita (Cnidaria, Scyphozoa). Biological Bulletin 200 (1): 92-96. http://dx.doi.org/10.2307/1543089

Dawson M.N. \& Martin L.E. 2001. Geographic variation and ecological adaptation in Aurelia (Scyphozoa, Semaeostomeae): some implications from molecular phylogenetics. Hydrobiologia 451: 259-273. http://dx.doi.org/10.1023/A:1011869215330

Dawson M.N., Gupta A.S. \& England M.H. 2005. Coupled biophysical global ocean model and molecular genetic analyses identify multiple introductions of cryptogenic species. Proceedings of the National Academy of Sciences 102 (34): 11968-11973. http://dx.doi.org/10.1073/pnas.0503811102

Gershwin L.A. 2001. Systematics and Biogeography of the Jellyfish Aurelia labiata (Cnidaria: Scyphozoa). Biological Bulletin 201 (1): 104-119. http://dx.doi.org/10.2307/1543531

Greenberg N., Garthwaite R.L. \& Potts D.C. 1996. Allozyme and morphological evidence for a newly introduced species of Aurelia in San Francisco Bay, California. Marine Biology 125 (2): 401-410. http:// dx.doi.org/10.1007/BF00346320 
Holst S. 2008. Grundlagen der Populationsentwicklung verschiedener Scyphozoa (Cnidaria) in der Deutschen Bucht. Dissertation, Universität Hamburg, Germany.

Holst S. 2012a. Effects of climate warming on strobilation and ephyrae production of North Sea scyphozoan jellyfish. Hydrobiologia 690 (1): 127-140. http://dx.doi.org/10.1007/s10750-012-1043-y

Holst S. 2012b. Morphology and development of benthic and pelagic life stages of North Sea jellyfish (Scyphozoa, Cnidaria) with special emphasis on the identification of ephyra stages. Marine Biology 159 (12): 2707-2722. http://dx.doi.org/10.1007/s00227-012-2028-0

Kramp P.L. 1961. Synopsis of the Medusae of the World. Journal of the Marine Biological Association of the United Kingdom 40: 1-469. http://dx.doi.org/10.1017/S0025315400007347

Lee P.L.M., Dawson M.N., Neill S.P., Robins P.E., Houghton J.D.R., Doyle T.K \& Hays G.C. 2013. Identification of genetically and oceanographically distinct blooms of jellyfish. Journal of the Royal Society Interface 10 (80): 20120920. http://dx.doi.org/10.1098/rsif.2012.0920

Linné C von. 1758. Systema Naturae. $10^{\text {th }}$ edition. Laurentius Salvius, Stockholm. http://dx.doi. org/10.5962/bhl.title. 542

Lucas C.H. 2001. Reproduction and life history strategies of the common jellyfish, Aurelia aurita, in relation to its ambient environment. Hydrobiologia 451: 229-246. http://dx.doi.org/10.1023/A:1011836326717

Lucas C.H., William M., Graham W.M. \& Widmer C. 2012. Jellyfish life histories: Role of polyps in forming and maintaining scyphomedusa populations. Advances in Marine Biology 63: 133-196. http:// dx.doi.org/10.1016/B978-0-12-394282-1.00003-X

Ma X., Purcell J.E. 2005. Effects of temperature, salinity and predators on mortality of and colonization by the invasive hydrozoan Moerisia lyonsi. Marine Biology 147 (1): 215-224. http://dx.doi.org/10.1007/ $\underline{\text { s00227-004-1538-9 }}$

Mayer A.G. 1910. Medusae of the World. Volume III. The Scyphomedusae. Carnegie Institution of Washington, Washington DC. http://dx.doi.org/10.5962/bhl.title.5996

Mayer A.G. 1917. Report on the Scyphomedusae collected by the United States Bureau of Fisheries Steamer Albatros in the Philippine Islands and Malay Archipelago. Bulletin of the United States National Museum 100: 175-233.

Mills C.E. 2001. Jellyfish blooms: are populations increasing globally in response to changing ocean conditions? Hydrobiologia 451: 55-68. http://dx.doi.org/10.1023/A:1011888006302

Miyake H., Terazaki M. \& Kakinuma Y. 2002. On the Polyps of the Common Jellyfish Aurelia aurita in Kagoshima Bay.Journal of Oceanography 58 (3): 451-459. http://dx.doi.org/10.1023/A:1021628314041

Péron F. \& Lesueur C.A. 1809. Histoire générale et particulière de tous les animaux qui composent la famille des Méduses. Annales du Muséum national d'histoire naturelle 14: 218-228.

Purcell J.E. 2007. Environmental effects on asexual reproduction rates of the scyphozoan Aurelia labiata. Marine Ecology Progress Series 348: 183-196. http://dx.doi.org/10.3354/meps07056

Purcell J.E. 2012. Jellyfish and Ctenophore Blooms Coincide with Human Proliferations and Environmental Perturbations. Annual Review of Marine Science 4: 209-235. http://dx.doi.org/10.1146/ annurev-marine-120709-142751

Purcell J.E., Uye S.I. \& Lo W.T. 2007. Anthropogenic causes of jellyfish blooms and their direct consequences for humans: a review. Marine Ecology Progress Series 350: 153-174. http://dx.doi. org $/ 10.3354 /$ meps 07093 
GAMBILL M. \& JARMS G., Comparison of different life stages of the genus Aurelia

Purcell J.E., Atienza D., Fuentes V., Olariaga A., Tilves U., Colahan C. \& Gili J.M. 2012. Temperature effects on asexual reproduction rates of scyphozoan species from the northwest Mediterranean Sea. Hydrobiologia 690 (1):169-180. http://dx.doi.org/10.1007/s10750-012-1047-7

R Core Team 2012. R: A Language and Environment for Statistical Computing. R Foundation for Statistical Computing, Vienna. Available from http://www.R-project.org/ [accessed 2 Nov. 2014]

Rees W.J. 1957. Proposed validation under the plenary powers of the generic name Aurelia Lamarck, 1816 (class Scyphozoa). Bulletin of Zoological Nomenclature 13 (1): 26-28.

Russell F.S. 1970. Medusae of the British Isles. Vol II. Pelagic Scyphozoa, with a Supplement to Vol. 1. Cambridge University Press, Cambridge.

Schroth W., Jarms G., Streit B. \& Schierwater B. 2002. Speciation and phylogeography in the cosmopolitan marine moon jelly, Aurelia sp. BMC Evolutionary Biology 2: 1-10. http://dx.doi.org/10.1186/1471$\underline{2148-2-1}$

Spangenberg D.B. 1964. New Observations on Aurelia. Transactions of the American Microscopical Society 83 (4): 448-455. http://dx.doi.org/10.2307/3224766

Spangenberg D.B. 1967. Iodine Induction of Metamorphosis in Aurelia. Journal of Experimental Zoology 165 (3): 441-450. http://dx.doi.org/10.1002/jez.1401650312

Spangenberg D.B. 1968. Recent studies of strobilation in jellyfish. In: Barnes H., Ansell A.D. \& Gibson R.N. (eds) Oceanography and Marine Biology: an Annual Review. Vol. 6: 231-247. University College London Press, London.

Stiasny G.A. 1938. Die Scyphomedusen des Roten Meeres. Noord-Hollandsche Uitgevers Maatschappij, Amsterdam.

Straehler-Pohl I. 2009. Phylogenie der Rhopaliophora (Scyphozoa und Cubozoa) und die Paraphylie der Rhizostomeae. Dissertation, Universität Hamburg, Germany.

Straehler-Pohl I. \& Jarms G. 2005. Life cycle of Carybdea marsupialis Linnaeus, 1758 (Cubozoa, Carybdeidae) reveals metamorphosis to be a modified strobilation. Marine Biology 147 (6): 1271-1277. http://dx.doi.org/10.1007/s00227-005-0031-4

Straehler-Pohl I. \& Jarms G. 2010. Identification key for young ephyrae: a first step for early detection of jellyfish blooms. Hydrobiologia 645 (1): 3-21. http://dx.doi.org/10.1007/s10750-010-0226-7

Straehler-Pohl I., Widmer C.L. \& Morandini A.C. 2011. Characterization of juvenile stages of some semaeostome Scyphozoa (Cnidaria), with recognition of a new family (Phacellophoridae). Zootaxa 2741: $1-37$.

Uchida T. 1934. A saemostome medusa with some characters of Rhizostomae. Proceedings of the Imperial Academy 10 (10): 698-700.

Uchida T. \& Nagao Z. 1963. The Metamorphosis of the Scyphomedusa, Aurelia limbata (Brandt). Annotationes zoologicae Japonenses 36 (2): 83-91.

Widmer C.L. 2005. Effects of temperature on growth of north-east Pacific moon jellyfish ephyrae, Aurelia labiata (Cnidaria: Scyphozoa). Journal of the Marine Biological Association of the United Kingdom 85 (3): 569-573. http://dx.doi.org/10.1017/S0025315405011495

Widmer C.L. 2006. Life cycle of Phacellophora camtschatica (Cnidaria: Scyphozoa). Invertebrate Biology 125 (2): 83-90. http://dx.doi.org/10.1111/j.1744-7410.2006.00043.x 
Willcox S., Moltschaniwskyj N.A. \& Crawford C. 2007. Asexual reproduction in scyphistomae of Aurelia sp.: Effects of temperature and salinity in an experimental study. Journal of Experimental Marine Biology and Ecology 353 (1): 107-114. http://dx.doi.org/10.1016/j.jembe.2007.09.006

Wrobel D. \& Mills C.E. 1998. Pacific Coast Pelagic Invertebrates: A Guide to the Common Gelatinous Animals. Sea Challengers and Monterey Bay Aquarium, Monterey, CA.

Manuscript received: 10 January 2014

Manuscript accepted: 16 September 2014

Published on: 26 December 2014

Topic editor: Rudy Jocqué

Desk editor: Charlotte Thionois

Printed versions of all papers are also deposited in the libraries of the institutes that are members of the EJT consortium: Muséum national d'Histoire naturelle, Paris, France; Botanic Garden Meise, Belgium; Royal Museum for Central Africa, Tervuren, Belgium; Natural History Museum, London, United Kingdom; Royal Belgian Institute of Natural Sciences, Brussels, Belgium; Natural History Museum of Denmark, Copenhagen, Denmark. 
GAMBILL M. \& JARMS G., Comparison of different life stages of the genus Aurelia

Appendix A. Morphological measurements of scyphistomae (mean $\pm \mathrm{sd})$ in $\mathrm{mm}$.

\begin{tabular}{|c|c|c|c|c|c|c|c|c|c|c|}
\hline Culture & TBL & CL & HL & MDD & StL & CDO & CD1 & CD2 & CD3 & StID \\
\hline 1 & $4.11 \pm 0.30$ & $2.67 \pm 0.33$ & $0.77 \pm 0.14$ & $1.98 \pm 0.24$ & $0.68 \pm 0.30$ & $1.79 \pm 0.14$ & $1.71 \pm 0.09$ & $1.61 \pm 0.10$ & $1.49 \pm 0.25$ & $0.50 \pm 0.23$ \\
\hline 2 & $2.82 \pm 0.73$ & $1.35 \pm 0.65$ & $1.11 \pm 0.18$ & $2.40 \pm 0.27$ & $0.35 \pm 0.13$ & $2.35 \pm 0.26$ & $2.15 \pm 0.29$ & $1.93 \pm 0.36$ & $1.60 \pm 0.40$ & $0.51 \pm 0.25$ \\
\hline 3 & $3.85 \pm 0.67$ & $2.11 \pm 0.31$ & $0.93 \pm 0.25$ & $2.15 \pm 0.33$ & $0.82 \pm 0.34$ & $2.14 \pm 0.39$ & $2.03 \pm 0.34$ & $1.85 \pm 0.39$ & $1.58 \pm 0.34$ & $0.54 \pm 0.06$ \\
\hline 4 & $5.23 \pm 0.45$ & $3.52 \pm 0.56$ & $0.69 \pm 0.22$ & $1.73 \pm 0.17$ & $1.02 \pm 0.55$ & $1.79 \pm 0.22$ & $1.78 \pm 0.23$ & $1.80 \pm 0.44$ & $1.74 \pm 0.46$ & $0.50 \pm 0.11$ \\
\hline 5 & $4.30 \pm 0.52$ & $2.18 \pm 0.54$ & $0.55 \pm 0.20$ & $1.69 \pm 0.18$ & $1.57 \pm 0.53$ & $1.64 \pm 0.19$ & $1.59 \pm 0.27$ & $1.55 \pm 0.31$ & $1.30 \pm 0.26$ & $0.24 \pm 0.05$ \\
\hline 6 & $2.89 \pm 0.34$ & $1.64 \pm 0.35$ & $0.62 \pm 0.20$ & $1.85 \pm 0.16$ & $0.63 \pm 0.16$ & $1.89 \pm 0.31$ & $1.72 \pm 0.36$ & $1.50 \pm 0.35$ & $1.28 \pm 0.34$ & $0.40 \pm 0.13$ \\
\hline 7 & $2.87 \pm 0.35$ & $1.47 \pm 0.23$ & $1.03 \pm 0.21$ & $1.95 \pm 0.22$ & $0.37 \pm 0.04$ & $1.93 \pm 0.16$ & $1.77 \pm 0.18$ & $1.65 \pm 0.17$ & $1.40 \pm 0.20$ & $0.50 \pm 0.18$ \\
\hline 8 & $3.46 \pm 0.32$ & $2.00 \pm 0.25$ & $0.80 \pm 0.22$ & $1.61 \pm 0.20$ & $0.66 \pm 0.19$ & $1.78 \pm 0.24$ & $1.79 \pm 0.29$ & $1.66 \pm 0.31$ & $1.41 \pm 0.32$ & $0.50 \pm 0.08$ \\
\hline 9 & $2.22 \pm 0.15$ & $1.13 \pm 0.14$ & $0.41 \pm 0.14$ & $1.52 \pm 0.05$ & $0.69 \pm 0.14$ & $1.43 \pm 0.18$ & $1.34 \pm 0.18$ & $1.11 \pm 0.27$ & $0.87 \pm 0.28$ & $0.32 \pm 0.10$ \\
\hline 10 & $1.89 \pm 0.19$ & $1.08 \pm 0.20$ & $0.41 \pm 0.16$ & $1.48 \pm 0.07$ & $0.40 \pm 0.07$ & $1.52 \pm 0.11$ & $1.55 \pm 0.14$ & $1.43 \pm 0.14$ & $1.15 \pm 0.19$ & $0.29 \pm 0.06$ \\
\hline 11 & $3.25 \pm 0.31$ & $2.11 \pm 0.19$ & $0.71 \pm 0.11$ & $1.57 \pm 0.07$ & $0.43 \pm 0.16$ & $1.54 \pm 0.08$ & $1.35 \pm 0.11$ & $1.35 \pm 0.10$ & $1.32 \pm 0.16$ & $0.39 \pm 0.07$ \\
\hline 12 & $1.18 \pm 0.26$ & $0.66 \pm 0.23$ & $0.31 \pm 0.08$ & $1.01 \pm 0.11$ & $0.20 \pm 0.04$ & $1.05 \pm 0.18$ & $0.95 \pm 0.15$ & $0.83 \pm 0.17$ & $0.66 \pm 0.17$ & $0.24 \pm 0.09$ \\
\hline 13 & $3.36 \pm 0.42$ & $2.25 \pm 0.22$ & $0.37 \pm 0.14$ & $2.00 \pm 0.27$ & $0.75 \pm 0.31$ & $1.91 \pm 0.21$ & $1.67 \pm 0.21$ & $1.53 \pm 0.17$ & $1.27 \pm 0.15$ & $0.38 \pm 0.14$ \\
\hline 14 & $2.02 \pm 0.33$ & $1.21 \pm 0.25$ & $0.55 \pm 0.16$ & $1.38 \pm 0.15$ & $0.25 \pm 0.22$ & $1.37 \pm 0.15$ & $1.22 \pm 0.14$ & $1.16 \pm 0.15$ & $1.03 \pm 0.22$ & $0.20 \pm 0.05$ \\
\hline 15 & $3.67 \pm 0.52$ & $2.47 \pm 0.38$ & $0.51 \pm 0.06$ & $1.89 \pm 0.24$ & $0.69 \pm 0.44$ & $1.89 \pm 0.38$ & $1.81 \pm 0.32$ & $1.65 \pm 0.25$ & $1.32 \pm 0.21$ & $0.47 \pm 0.06$ \\
\hline 16 & $2.26 \pm 0.34$ & $0.96 \pm 0.36$ & $0.48 \pm 0.18$ & $1.54 \pm 0.06$ & $0.82 \pm 0.20$ & $1.39 \pm 0.05$ & $1.16 \pm 0.06$ & $0.93 \pm 0.10$ & $0.71 \pm 0.06$ & $0.24 \pm 0.02$ \\
\hline 17 & $2.76 \pm 0.32$ & $1.90 \pm 0.33$ & $0.46 \pm 0.08$ & $2.09 \pm 0.15$ & $0.41 \pm 0.12$ & $2.13 \pm 0.17$ & $2.11 \pm 0.16$ & $1.93 \pm 0.24$ & $1.52 \pm 0.35$ & $0.45 \pm 0.15$ \\
\hline
\end{tabular}

Appendix B. Morphological measurements of ephyrae (mean $\pm \mathrm{sd}$ ) in $\mathrm{mm}$.

\begin{tabular}{ccccccccc}
\hline Culture & TBD & CDD & TMLL & LStL & RLL & ML & AdD & RhTI \\
\hline $\mathbf{1}$ & $3.44 \pm 0.23$ & $1.36 \pm 0.13$ & $1.03 \pm 0.06$ & $0.52 \pm 0.02$ & $0.51 \pm 0.05$ & $0.38 \pm 0.05$ & $1.45 \pm 0.13$ & $2.34 \pm 0.18$ \\
\hline $\mathbf{2}$ & $3.54 \pm 0.32$ & $1.32 \pm 0.10$ & $1.15 \pm 0.10$ & $0.56 \pm 0.04$ & $0.59 \pm 0.06$ & $0.37 \pm 0.06$ & $1.43 \pm 0.10$ & $2.40 \pm 0.18$ \\
\hline $\mathbf{6}$ & $3.27 \pm 0.12$ & $1.06 \pm 0.03$ & $1.09 \pm 0.05$ & $0.66 \pm 0.03$ & $0.43 \pm 0.03$ & $0.32 \pm 0.03$ & $1.21 \pm 0.02$ & $2.41 \pm 0.06$ \\
\hline $\mathbf{8}$ & $2.92 \pm 0.09$ & $1.29 \pm 0.04$ & $0.77 \pm 0.04$ & $0.39 \pm 0.03$ & $0.38 \pm 0.04$ & $0.29 \pm 0.05$ & $1.38 \pm 0.03$ & $2.05 \pm 0.02$ \\
\hline $\mathbf{9}$ & $2.76 \pm 0.21$ & $0.95 \pm 0.07$ & $0.92 \pm 0.08$ & $0.46 \pm 0.06$ & $0.46 \pm 0.03$ & $0.26 \pm 0.02$ & $1.05 \pm 0.07$ & $1.98 \pm 0.19$ \\
\hline $\mathbf{1 4}$ & $3.37 \pm 0.11$ & $1.21 \pm 0,08$ & $1.10 \pm 0.03$ & $0.56 \pm 0.02$ & $0.55 \pm 0.02$ & $0.29 \pm 0.03$ & $1.31 \pm 0.07$ & $2.41 \pm 0.12$ \\
\hline $\mathbf{1 6}$ & $3.97 \pm 0.16$ & $1.39 \pm 0.10$ & $1.33 \pm 0.06$ & $0.68 \pm 0.04$ & $0.65 \pm 0.05$ & $0.50 \pm 0.03$ & $1.48 \pm 0.09$ & $2.89 \pm 0.08$ \\
\hline
\end{tabular}

